\title{
Magnetic anomaly interpretation for a 2D fault-like geologic structures utilizing the global particle swarm method
}

Khalid S. ESSA ( $\square$ essa@sci.cu.edu.eg )

Cairo University https://orcid.org/0000-0002-4183-9617

Yves Géraud

University of Lorraine: Universite de Lorraine

Alan B. Reid

Reid Geophysics Ltd

\section{Research Article}

Keywords: Global particle swarm, moving average, fault, depth

Posted Date: August 24th, 2021

DOl: https://doi.org/10.21203/rs.3.rs-785255/v1

License: (c) (i) This work is licensed under a Creative Commons Attribution 4.0 International License.

Read Full License 


\section{Magnetic anomaly interpretation for a 2D fault-like geologic}

\section{structures utilizing the global particle swarm method}

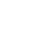

Khalid S. Essa ${ }^{*}$, Yves Géraud $^{2}$, Alan B. Reid ${ }^{3}$

${ }^{1}$ Department of Geophysics, Faculty of Science, Cairo University, Giza, P.O. 12613,

Egypt.

${ }^{2}$ GeoRessources Laboratory, University of Lorraine, Nancy, 54500, France.

${ }^{3}$ Reid Geophysics Ltd, 116a Seaside, Eastbourne BN22 7QP, UK.

*Corresponding author:

Tel. +20235676794

Fax: +20235727556

E-mail: khalid_sa_essa@yahoo.com

Running head: Magnetic data interpretation

Funding: No funding.

Conflicts of interest/Competing interests: No conflict.

Data availability statement: Data used for this study will be available from the corresponding author upon request. 


\section{Abstract}

We establish a method to elucidate the magnetic anomaly due to $2 \mathrm{D}$ fault structures, with an evaluation of first moving average residual anomalies utilizing filters of increasing window lengths. After that, the buried fault parameters are estimated using the global particle swarm method. The goodness of fit among the observed and the calculated models is expressed as the root mean squared (RMS) error. The importance of studying and delineating the fault parameters, which include the amplitude factor, the depth to the upper edge, the depth to the lower edge, the fault dip angle, and the position of the origin of the fault, is: (i) solving many problem-related engineering and environmental applications, (ii) describing the accompanying mineralized zones with faults, (iii) describing geological deformation events, (iv) monitoring the subsurface shear zones, (v) defining the environmental effects of the faults before organizing any investments, and (vi) imaging subsurface faults for different scientific studies.

Finally, we show the method applied to two theoretical models including the influence of the regional background and the multi-fault effect and to real field examples from Australia and Turkey. Available geologic and geophysical information corroborates our interpretations.

Keywords: Global particle swarm, moving average, fault, depth. 


\section{Introduction}

The magnetic method uses the magnetization contrasts between different lithologies to examine environmental or geologic subsurface problems of various kinds. These problems include mineral and ore detection (Innocent et al., 2019; Shah et al. 2020; Mehanee et al. 2021), hydrocarbon exploration (Al-Farhan et al. 2019; Osinowo and Taiwo 2020), archaeological investigation (Powell et al. 2012; Pisz et al. 2020), geotechnical engineering (Hasan et al. 2020; Igwe and Umbugadu 2020), cave discovery (Mochales et al. 2008; Orfanos and Apostolopoulos 2012) and geothermal exploration (Abdel Zaher et al. 2018; Abraham and Alile 2019; Zhao et al. 2020). Inversion of magnetic data for arbitrarily complex structure is an ill-posed and nonunique problem (Hinze et al. 2013; Utsugi 2019). Interpretation for simple geometric shapes reduces the complexity and offers usable best-fit solutions (Singh et al. 2000; Tlas and Asfahani 2011; Abo-Ezz and Essa 2016; Ghanati et al. 2017).

Graphical and numerical methods have long been used to appraise simple subsurface geometric-model parameters (Gay 1963; Abdelrahman et al. 2009; Tlas and Asfahani 2015; Karimi and Shirzaditabar 2017; Biswas et al. 2017; Essa and Abo-Ezz 2021). Global optimization algorithms have been successfully applied to full complete interpretation (Asfahani and Tlas 2007; Biswas and Acharya 2016; Di Maio et al. 2020; Essa 2021; Essa et al. 2021).

In this study we present an extended application of the particle swarm method to elucidate the magnetic residual anomaly of 2D fault-like geologic structures. A residual magnetic anomaly is computed using a first moving average to estimate a first-order regional from the observed magnetic anomaly. The proposed method was verified on two theoretical examples. The first example demonstrates the influence of 
the linear regional field and the second example shows the detection of subsurface multi-faults. The appraised fault parameters $\left(\mathrm{K}, \mathrm{z}_{1}, \mathrm{z}_{2}, \theta, \beta\right.$, and $\mathrm{c}-$ see Figure 1$)$ show that the proposed method is firm. After that, the suggested method was applied on two real datasets from Australia and Turkey to obtain the subsurface fault parameters. Finally, the results from the examples studied show that the proposed method can tolerate noise and regional background in the observed field and give a good insight into subsurface faults.

\section{The particle swarm method}

The particle swarm optimization is carefully distinguished and has been used to address a variety of geophysical problems. The development of the method was fully described in the published literature (Singh and Biswas 2016; Grandis and Maulana 2017; Essa and Munschy 2019; Essa and Géraud 2020; Essa 2021), and we do not repeat it here. Instead, we accentuation on its considerable profits in vanquishing the ill-posedness and non-uniqueness of magnetic data inversion. Furthermore, it is firm, vigorous, and effective in attaining an optimal global solution. The power of the technique is typically seen in the theoretical and field models presented below. (1) 93 4 15 $\%$ " $\sqrt{20}$ $\sqrt{20}$ 


\section{Forward modelling}

For a $2 \mathrm{D}$ fault model, the magnetic anomaly $(\mathrm{T})$ at an observation point $\left(\mathrm{P}\left(\mathrm{x}_{\mathrm{j}}\right)\right)$ along a profile (Fig. 1) is given by (e.g. Murthy et al. 2001; Aydin 2008):

$$
\mathrm{T}\left(\mathrm{x}_{\mathrm{j}}\right)
$$

$$
=K\left\langle\left\{\cos (\theta+\beta)\left[\operatorname{atan}\left(\frac{\left(x_{j}-c\right)+\left(z_{2}-z_{1}\right) \cot \beta}{z_{2}}\right)-\operatorname{atan}\left(\frac{x_{j}-c}{z_{1}}\right)\right]\right\}\right.
$$

$$
106+\left\{\sin (\theta+\beta)\left[\ln \left(\frac{\left(\left(\left(x_{j}-c\right)+\left(z_{2}-z_{1}\right) \cot \beta\right)^{2}+z_{2}^{2}\right)^{0.5}}{\left(\left(x_{j}-c\right)^{2}+z_{1}^{2}\right)^{0.5}}\right)\right]\right\} \text {, }
$$

where $\mathrm{x}_{\mathrm{j}}$ is the coordinate of the observation station $(\mathrm{km}), \mathrm{c}$ is the trace point of the fault $(\mathrm{km}), \mathrm{z}_{1}$ is the depth to the upper edge of the fault $(\mathrm{km}), \mathrm{z}_{2}$ is the depth to lower edge $(\mathrm{km}), \beta$ is an inclination angle which include the dip of the effective magnetization and the direction of the measurement $\left(^{\circ}\right), \theta$ is the fault $\operatorname{dip}\left(^{\circ}\right)$, and $\mathrm{K}$ (nT) is the amplitude factor or intensity of magnetization, which depends on the susceptibility contrast (see Figure 1).

\section{The first moving average method}

The total magnetic field anomaly can be decomposed as a residual and a respectively linear regional field, which are related to shallow and deep geologic structures, is:

$$
\Delta \mathrm{T}_{\mathrm{o}}\left(\mathrm{x}_{\mathrm{j}}\right)=\mathrm{T}\left(\mathrm{x}_{\mathrm{j}}\right)+\operatorname{Reg}\left(\mathrm{x}_{\mathrm{j}}\right)
$$

where $\Delta \mathrm{T}_{\mathrm{o}}\left(\mathrm{x}_{\mathrm{j}}\right)$ is the observed magnetic anomaly, $\mathrm{T}\left(\mathrm{x}_{\mathrm{j}}\right)$ represents the magnetic anomaly due to the $2 \mathrm{D}$ fault (residual anomaly) and $\operatorname{Reg}\left(\mathrm{x}_{\mathrm{j}}\right)$ is the magnetic anomaly due to regional anomaly (deep structures). Removal of the impact of the regional field 
is considered as one of the most important difficulties in magnetic data elucidation. The first moving average method application is regularly applied for this issue.

Griffin (1949) explained that the first moving average regional is:

$$
\operatorname{Reg}\left(\mathrm{x}_{\mathrm{j}}\right)=\frac{\sum_{\mathrm{j}=-\mathrm{n}}^{\mathrm{j}=+\mathrm{n}} \Delta \mathrm{T}_{\mathrm{o}}\left(\mathrm{x}_{\mathrm{i}+\mathrm{j}}\right)}{2 \mathrm{n}+1}, \mathrm{n}=1,2,3, \ldots
$$

where the window length operator (s-value) for calculating the moving average regional is equal $2 n+1$. Thus, the moving average residual anomaly is:

$$
\mathrm{R}\left(\mathrm{x}_{\mathrm{j}}, \mathrm{s}\right)=\Delta \mathrm{T}_{\mathrm{o}}\left(\mathrm{x}_{\mathrm{j}}\right)-\frac{\sum_{\mathrm{j}=-\mathrm{n}}^{\mathrm{j}=+\mathrm{n}} \Delta \mathrm{T}_{\mathrm{o}}\left(\mathrm{x}_{\mathrm{i}+\mathrm{j}}\right)}{\mathrm{s}} .
$$

The particle swarm optimization method is utilized to the residual (calculated above) to obtain the $2 \mathrm{D}$ fault parameters $\left(\mathrm{K}, \mathrm{z}_{1}, \mathrm{z}_{2}, \theta, \beta\right.$, and $\left.\mathrm{c}\right)$.

Finally, the optimum magnetic anomaly fit is reached by seeking the minimum $\operatorname{RMS}$ misfit $(\lambda)$, which is defined as:

$$
\lambda=\sqrt{\frac{1}{N} \sum_{i=1}^{N}\left[R_{j}^{o}\left(x_{j}\right)-R_{j}^{c}\left(x_{j}\right)\right]^{2}},
$$

where $\mathrm{N}$ is the number of measured points, $\mathrm{R}_{\mathrm{j}}^{\mathrm{O}}$ is the observed magnetic anomaly and $\mathrm{R}_{\mathrm{j}}^{\mathrm{c}}$ is the calculated anomaly at the point $\mathrm{x}_{\mathrm{j}}$. Figure 2 displays the flow diagram for the proposed method.

\section{Theoretical models}

We investigated the uncertainties and stability of the suggested technique for assessing the $2 \mathrm{D}$ fault model parameters $\left(\mathrm{K}, \mathrm{z}_{1}, \mathrm{z}_{2}, \theta, \beta\right.$, and $\left.\mathrm{c}\right)$ by studying the following two theoretical examples, which revealed the impact of imposed linear regional background and multi-faults effects exemplified by a horst. 


\section{Model 1: Impact of linear regional field}

This composite model uses the expected magnetic anomaly $\left(\Delta \mathrm{T}_{0}\right)$ for the $2 \mathrm{D}$ fault described by Equation (1) with the parameters: $\mathrm{K}=400 \mathrm{nT}, \mathrm{z}_{1}=4 \mathrm{~km}, \mathrm{z}_{2}=7 \mathrm{~km}, \theta=$ $35^{\circ}, \beta=30^{\circ}, \mathrm{c}=50 \mathrm{~km}$, and profile length $=100 \mathrm{~km}$ and the influence of some unknown deep-structure (regional anomaly) representing by a first-order polynomial $\left(2 x_{j}+50\right)($ Fig. 3a).

We have applied the moving average method to estimate the first moving average residual anomalies by implementing equation (4) applying several window lengths $(\mathrm{s}=3,5,7,9$, and $11 \mathrm{~km})$ (Fig. 3b). Next, the particle swarm was used to gauge the 2D fault parameters $\left(\mathrm{K}, \mathrm{z}_{1}, \mathrm{z}_{2}, \theta, \beta\right.$, and $\left.\mathrm{c}\right)$ (Table 1). In Table 1 , the ranges used for all parameters are presented and the results of the estimated fault parameters are: $\mathrm{K}=399.08 \pm 0.65 \mathrm{nT}, \mathrm{z}_{1}=3.99 \pm 0.01 \mathrm{~km}, \mathrm{z}_{2}=6.99 \pm 0.01 \mathrm{~km}, \theta=34.99 \pm 0.02^{\circ}, \beta=$ $29.99 \pm 0.02^{\circ}$, and $\mathrm{c}=49.99 \pm 0.02 \mathrm{~km}$. The errors in each parameter are vanishingly small and the RMS misfit among the observed and the estimated anomalies is $0.22 \mathrm{nT}$ (Fig. 3f). For a noise-free model, this is gratifying but unsurprising.

This method's performance was examined after inserting $10 \%$ random noise on the above composite magnetic anomaly (Fig. 3c) applying the next form:

$$
\Delta \mathrm{T}_{\mathrm{o}}^{\mathrm{rand}}\left(\mathrm{x}_{\mathrm{j}}\right)=\Delta \mathrm{T}_{\mathrm{o}}\left(\mathrm{x}_{\mathrm{j}}\right) \times[1+\lambda *(\operatorname{RAND}(\mathrm{j})-0.5)] \text {, }
$$

where $\Delta \mathrm{T}_{\mathrm{o}}^{\mathrm{rand}}\left(\mathrm{x}_{\mathrm{j}}\right)$ is the synthetic model with noise $(\mathrm{nT}), \Delta \mathrm{T}_{\mathrm{o}}\left(\mathrm{x}_{\mathrm{j}}\right)$ is original model (nT), $\lambda$ is percentage level, and RAND(i) is a pseudo-random number whose range is $[0,1]$

Application of the moving average method with the same window lengths yielded noisy residual magnetic anomalies (Fig. 3d). The global particle swarm optimization gave estimated buried fault structure parameters (Table 1). Table 1 reveals each parameter result as follows: $\mathrm{K}=386.70 \pm 3.50 \mathrm{nT}, \mathrm{z}_{1}=3.83 \pm 0.07 \mathrm{~km}, \mathrm{z}_{2}=$ 
$6.78 \pm 0.05 \mathrm{~km}, \theta=33.69 \pm 0.57^{\circ}, \beta=28.28 \pm 0.55^{\circ}$, and $\mathrm{c}=48.71 \pm 0.93 \mathrm{~km}$, with $3.33 \%$, $4.15 \%, 3.17 \%, 3.74 \%, 5.73 \%$, and $2.58 \%$, respectively. The misfit $(\lambda=22.01 \mathrm{nT})$ amongst the observed anomaly and the assessed magnetic anomalies is revealed in Fig. 3f.

The results for $0 \%$ and $10 \%$ noise level imposed on the composite magnetic anomaly reveals the suggested method was capable to cope with the regional background and noise and created valid results.

\section{Model 2: Multi-fault consisting of a horst}

We examined a $100 \mathrm{~km}$ composite magnetic profile due to multi-fault structures consisting of a horst block with the following parameters: $\mathrm{K}_{1}=300 \mathrm{nT}, \mathrm{z}_{11}=3 \mathrm{~km}$, $\mathrm{z}_{21}=10 \mathrm{~km}, \theta_{1}=120^{\circ}, \beta_{1}=20^{\circ}$, and $\mathrm{c}_{1}=53 \mathrm{~km}$ for body 1 and $\mathrm{K}_{2}=200 \mathrm{nT}, \mathrm{z}_{12}=5$ $\mathrm{km}, \mathrm{z}_{22}=10 \mathrm{~km}, \theta_{2}=135^{\circ}, \beta_{2}=20^{\circ}$, and $\mathrm{c}_{2}=47 \mathrm{~km}$ for body 2 along $100 \mathrm{~km}$ profile (Fig $4 \mathrm{a}$ and $4 \mathrm{e})$.

The first moving average method was employed to the magnetic anomaly exploiting several s-values ( $\mathrm{s}=3,5,7,9$, and $11 \mathrm{~km})$ (Fig. 4b); subsequent the particle swarm method was claimed in order to assess the subsurface faults structures parameters (Table 2). Table 2 indicates the results for the two fault structures, which consist of a horst block, which are: $\mathrm{K}_{1}=290.56 \pm 3.96 \mathrm{nT}, \mathrm{z}_{11}=2.93 \pm 0.02 \mathrm{~km}, \mathrm{z}_{21}=$ $10.00 \pm 0.05 \mathrm{~km}, \theta_{1}=118.18 \pm 0.84^{\circ}, \beta_{1}=19.46 \pm 0.47^{\circ}$, and $\mathrm{c}_{1}=52.59 \pm 0.35 \mathrm{~km}$, and the error of $\mathrm{K}_{1}, \mathrm{z}_{11}, \mathrm{z}_{21}, \theta_{1}, \beta_{1}$, and $\mathrm{c}_{1}$ are: $3.15 \%, 2.33 \%, 0 \%, 1.52 \%, 2.72 \%$, and $0.77 \%$, respectively, while the calculated parameters of the second model (Body 2; Fig. $4 \mathrm{e}$ ) are: $\mathrm{K}_{2}=195.17 \pm 2.031 \mathrm{nT}, \mathrm{z}_{12}=4.78 \pm 0.15 \mathrm{~km}, \mathrm{z}_{22}=8.92 \pm 0.50 \mathrm{~km}, \theta_{2}=$ $134.04 \pm 3.06^{\circ}, \beta_{2}=18.97 \pm 0.73^{\circ}$, and $c_{2}=46.22 \pm 0.62 \mathrm{~km}$, and the error of $\mathrm{K}_{2}, \mathrm{z}_{12}, \mathrm{z}_{22}$, $\theta_{2}, \beta_{2}$, and $c_{2}$ are: $2.41 \%, 4.48 \%, 10.76 \%, 0.71 \%, 5.16 \%$, and $1.66 \%$, correspondingly, and the RMS misfit ( $\lambda$-value) is $12.81 \mathrm{nT}$. 
We then imposed a $10 \%$ random error on the anomaly (Fig. 4c) using the

previous (Eq. 6). The first moving average residual magnetic anomalies were calculated using the same s-values as before (Fig. 4d), and the fault parameters estimated via the global particle swarm method (Table 2). As shown in Table 2, the predicated parameters of the first model (Body 1; Fig. 4e) are: $\mathrm{K}_{1}=282.13 \pm 8.53 \mathrm{nT}$, $\mathrm{z}_{11}=2.91 \pm 0.08 \mathrm{~km}, \mathrm{z}_{21}=9.56 \pm 0.60 \mathrm{~km}, \theta_{1}=118.92 \pm 3.76^{\circ}, \beta_{1}=19.96 \pm 111^{\circ}$, and $\mathrm{c}_{1}=$ $51.82 \pm 1.12 \mathrm{~km}$, and the errors in $\mathrm{K}_{1}, \mathrm{z}_{11}, \mathrm{z}_{21}, \theta_{1}, \beta_{1}$, and $\mathrm{c}_{1}$ are: $5.96 \%, 2.93 \%, 4.38 \%$, $0.90 \%, 0.21 \%$, and $2.22 \%$, respectively, while the estimated parameters of the second model (Body 2; Fig. 4e) are: $\mathrm{K}_{2}=193.95 \pm 7.78 \mathrm{nT}, \mathrm{z}_{12}=4.88 \pm 0.32 \mathrm{~km}, \mathrm{z}_{22}=$ $9.14 \pm 0.80 \mathrm{~km}, \theta_{2}=133.09 \pm 1.88^{\circ}, \beta_{2}=18.58 \pm 0.80^{\circ}$, and $\mathrm{c}_{2}=47.35 \pm 0.68 \mathrm{~km}$, and the error of $\mathrm{K}_{2}, \mathrm{z}_{12}, \mathrm{z}_{22}, \theta_{2}, \beta_{2}$, and $\mathrm{c}_{2}$ are: $3.02 \%, 2.40 \%, 8.64 \%, 1.41 \%, 7.12 \%$, and $0.75 \%$, correspondingly, with an RMS misfit of $26.07 \mathrm{nT}$.

The misfit amongst the original anomaly and the calculated anomaly (Fig. 4a and Fig. 4c) is shown in Figure 4f.

In summary, the particle swarm method has been employed on two theoretical models, which represent the effect of a linear regional background and noise (Model 1), and the effect of multi-faults (Model 2). A respectable match of the observed to the calculated model parameters has been found and the errors in all assessed parameters do not increase more than $10 \%$.

\section{Real data examples}

To inspect the practical applicability of the proposed method, two real data sets were collected from the available published literature from Australia and Turkey. The particle swarm method was used to invert the observed magnetic field values to achieve the optimum fit of the fault parameters $\left(\mathrm{K}, \mathrm{z}_{1}, \mathrm{z}_{2}, \theta, \beta\right.$, and $\left.\mathrm{c}\right)$, which were 
then compared with current geologic information and any additional geophysical outcomes.

\section{The Perth basin field example, Australia}

The Perth Basin is placed at the western part of Australia and is elongated north-tosouth. It is effectively the southern part of the Carnarvon Basin and covers an area of about $100,000 \mathrm{~km}^{2}$. It is considered as an important basin for hydrocarbon exploration in Australia and includes more than twenty commercial oil and gas fields. The Perth Basin is a huge rift structure, which formed during intra-continental rifting and developed through eventual division of India from Australia. This basin is separated to fifteen sub-basins, which record a big sedimentary fill ranging from Permian to Recent age (Harris 1994; Olierook et al. 2015) (Fig. 5a).

The observed magnetic anomaly owing to a fault-like geologic structure was collected at the Western border of the Perth basin, Australia (Qureshi and Nalaye 1978). The profile length of $40 \mathrm{~km}$ was digitized at $1 \mathrm{~km}$ intervals (Fig. 5b). This digitized anomaly was used to gauge the parameters $\mathrm{K}, \mathrm{z}_{1}, \mathrm{z}_{2}, \theta, \beta$, and $\mathrm{c}$ using the proposed method for available first moving average residual magnetic anomalies (Fig. 5c) using $\mathrm{s}=3,5,7,9$, and $11 \mathrm{~km}$ (Table 3). Table 3 demonstrates the extents and results of the fault model parameters as follows: $\mathrm{K}=146.62 \pm 1.04 \mathrm{nT}, \mathrm{z}_{1}=5.98 \pm 0.26$ $\mathrm{km}, \mathrm{z}_{2}=14.99 \pm 0.35 \mathrm{~km}, \theta=95.64 \pm 0.29^{\circ}, \beta=-21.14 \pm 1.92^{\circ}$, and $\mathrm{c}=18.05 \pm 0.42 \mathrm{~km}$. The misfit (RMS value, $\lambda=7.18 \mathrm{nT}$ ) of the observed anomaly and the predicated magnetic anomalies is given in profile in Fig. 5e.

The estimated fault parameters by the application of the global particle swarm convolved with the first moving average have a respectable agreement with the results achieved from borehole information (Qureshi and Nalaye 1978) and additional 
interpretation methods (Rao and Babu 1983; Asfahani and Tlas 2007; Tlas and Asfahani 2011; Di Maio et al. 2020) (Table 4). In more detail, the previous inversion methods used the observed magnetic anomaly as a residual anomaly, with no attempt to remove a regional, which is not clear in the respective papers.

\section{The Şereflikoçhisar-Aksaray fault field example, Turkey}

The city of Aksaray is situated in the southwest of the central part of Anatolia between the Sakarya Region and Pontides (Eurasian Plate) in the north and the Anatolide-Tauride Platform in the south. The area is surrounded by young sediments consisting of tertiary units and surrounded by massive metamorphic rocks, comprised of mica schists, graphite schists, phyllites quartzites and marbles. Also, a granitoid intrusion is found in the eastern part of the Şereflikoçhisar-Aksaray fault and Cappadocian volcanic rocks occasioned from tectonic activities due to the subduction of the Neo-Tethys Ocean. (Arikan 1975; Aydemir and Ates 2006; Bilim et al. 2015) (Fig. 6a).

The magnetic anomaly profile for the Aksaray fault, Turkey (Aydemir and Ates, 2006; figure 6) with a length of $25 \mathrm{~km}$ and digitized at an interim of $0.625 \mathrm{~km}$ (Fig. 6b) was employed. A complete interpretation of this magnetic anomaly was done by applying the same procedure as above. The first moving average residual magnetic anomalies were achieved for numerous window lengths $(\mathrm{s}=1.875,3.125$, 4.375, 5.625, and $6.875 \mathrm{~km}$ ) (Fig. 6c). The particle swarm method was employed to these anomalies to evaluate the fault parameters (Table 5). The results in Table 5 are: $\mathrm{K}=146.07 \pm 1.38 \mathrm{nT}, \mathrm{z}_{1}=1.95 \pm 0.07 \mathrm{~km}, \mathrm{z}_{2}=4.60 \pm 0.15 \mathrm{~km}, \theta=163.29 \pm 0.98^{\circ}, \beta=$ $33.48 \pm 0.49^{\circ}$, and $\mathrm{c}=540.53 \pm 2.83 \mathrm{~km}$. As well, the misfit $(\mathrm{RMS}$ value $\lambda=25.93 \mathrm{nT})$ among the observed anomaly and the estimated magnetic anomalies is depicted in Fig. 
6e. Lastly, the fault model parameters estimated by the proposed method show good agreement with published values, especially the depths to the top and bottom, from Aydemir and Ates (2006) $\left(\mathrm{z}_{1}=1.92 \mathrm{~km}\right.$ and $\left.\mathrm{z}_{2}=4.61 \mathrm{~km}\right)$.

\section{Conclusions}

The application of the particle swarm method for interpreting the first moving average residual magnetic anomalies, which is produced from the observed magnetic anomaly using several window lengths, is likely to be useful in geophysical exploration, including hydrocarbon, mineral and ore exploration because it offers several benefits, namely: (1) it removes the effect of deep structures (regional background response), (2) it eliminates the effect of neighbouring structures and noise response, (3) it infers the fault model parameters with a good accuracy, and (4) the method is automatic. The accuracy and pertinence of the proposed method were verified by examining two appropriate theoretical models and two real data sets from Australia and Turkey. From results demonstrate that, the proposed method is robust and stable. This method can be extended to more complicated cases, which we propose to do in a future study. 


\section{References}

Abdel Zaher M, Saibi H, Mansour K, Khalil A, Soliman M (2018) Geothermal exploration using airborne gravity and magnetic data at Siwa Oasis, Western Desert, Egypt. Renew Sustain Energy Rev 82: 3824-3832.

Abdelrahman EM, Soliman KS, El-Araby TM, Abo-Ezz ER, Essa KS (2009) A leastsquares standard deviation method to interpret magnetic anomalies due to thin dikes. Near Surf Geophys 7: 41-46.

Abo-Ezz ER, Essa KS (2016) A least-squares minimization approach for model parameters estimate by using a new magnetic anomaly formula. Pure Appl Geophys 173: 1265-1278.

Abraham EM, Alile OM (2019) Modelling subsurface geologic structures at the Ikogosi geothermal field, southwestern Nigeria, using gravity, magnetics and seismic interferometry techniques. J Geophys Eng 16: 729-741.

Al-Farhan M, Oskooi B, Ardestani VE, Abedi M, Al-Khalidy A (2019) Magnetic and gravity signatures of the Kifl oil field in Iraq. J Pet Sci Eng 183: 106397.

Arıkan Y (1975) Tuz Golu havzasının jeolojisi ve petrol imkanları [Geology and the oil possibilities of the Tuz Gölü Basin]. General Directorate of Mineral Research and Exploration (MTA) Bulletin 85: 17-38.

Asfahani J, Tlas M (2007) A robust nonlinear inversion for the interpretation of magnetic anomalies caused by faults, thin dikes and spheres like structure using stochastic algorithms. Pure Appl Geophys 164: 2023-2042. 
Aydemir A, Ates A (2006) Interpretation of Suluklu-Cihanbeyli-Goloren Magnetic Anomaly, Central Anatolia, Turkey: An integration of geophysical data. Phys Earth Planet Inter 159: 167-182.

Aydin I (2008) Estimation of the location and depth parameters of 2D magnetic sources using analytical signals. J Geophys Eng 5: 281-289.

Bilim F, Aydemir A, Ateş A (2015) Determination of block rotations and the Curie Point Depths of magnetic sources along the NW-SE-trending SülüklüCihanbeyli-Gölören and Şereflikoçhisar-Aksaray Fault Zones, Central Anatolia, Turkey. Geodin Acta 27: 202-2012.

Biswas A, Parija MP, Kumar S (2017) Global nonlinear optimization for the interpretation of source parameters from total gradient of gravity and magnetic anomalies caused by thin dyke. Ann Geophys 60: G0218.

Biswas A, Acharya T (2016) A very fast simulated annealing method for inversion of magnetic anomaly over semi-infinite vertical rod-type structure. Model Earth Syst Environ 2: 198.

Di Maio R, Milano L, Piegari E (2020) Modeling of magnetic anomalies generated by simple geological structures through Genetic-Price inversion algorithm. Phys Earth Planet Inter 305: 106520.

Essa KS (2021) Evaluation of the parameters of fault-like geologic structure from the gravity anomalies applying the particle swarm. Environ Earth Sci 80: 489.

Essa KS, Abo-Ezz ER (2021) Potential field data interpretation to detect the parameters of buried geometries by applying a nonlinear least-squares approach. Acta Geod Geophys 56: 387-406. 
Essa KS, Géraud Y (2020) Parameters estimation from the gravity anomaly caused by the two-dimensional horizontal thin sheet applying the global particle swarm algorithm. J Pet Sci Eng 193: 107421.

Essa KS, Géraud Y, Diraison M (2021) Fault parameters assessment from the gravity data profiles using the global particle swarm optimization. J Pet Sci Eng 207: 109129.

Essa KS, Munschy M (2019) Gravity data interpretation using the particle swarm optimization method with application to mineral exploration. J Earth Syst Sci 128: 123.

Gay SP (1963) Standard curves for interpretation of magnetic anomalies over long tabular bodies. Geophysics 28: 161-200.

Ghanati R, Ghari H, Fatehi M (2017) Regularized nonlinear inversion of magnetic anomalies of simple geometric models using Occam's method: an application to the Morvarid iron-apatite deposit in Iran. Acta Geod Geophys 52: 555-580.

Grandis H, Maulana Y (2017) Particle Swarm Optimization (PSO) for Magnetotelluric (MT) 1D Inversion Modeling. IOP Conf. Ser.: Earth Environ Sci 62: 012033

Griffin WR (1949) Residual gravity in theory and practice. Geophysics 14: 39-58.

Hasan M, Shang Y, Jin W, Akhter G (2020) An engineering site investigation using non-invasive geophysical approach. Environ Earth Sci 79: 265.

Harris LB (1994) Structural and tectonic synthesis for the Perth Basin, Western Australia. J Pet Geol 17: 129-156. 
Hinze WJ, von Frese RRB, Saad AH (2013) Gravity and magnetic exploration: principles, practices, and applications. Cambridge University Press, p.512.

Igwe O, Umbugadu AA (2020) Characterization of structural failures founded on soils in Panyam and some parts of Mangu, Central Nigeria. Geoenvironmental Disasters 7: 7.

Innocent AJ, Chidubem EO, Chibuzor NA (2019) Analysis of aeromagnetic anomalies and structural lineaments for mineral and hydrocarbon exploration in Ikom and its environs southeastern Nigeria, J Afr Earth Sci 151: 274-285.

Karimi K, Shirzaditabar F (2017) Using the ratio of the magnetic field to the analytic signal of the magnetic gradient tensor in determining the position of simple shaped magnetic anomalies. J Geophys Eng 14: 769-779.

Mehanee S, Essa KS, Diab ZE (2021) Magnetic Data Interpretation Using a New Rparameter Imaging Method with Application to Mineral Exploration. Nat Resour Res 30: 77-95.

Mochales T, Casas AM, Pueyo EL, Pueyo O, Roman MT, Pocoyi A, Soriano MA, Anson D (2008) Detection of underground cavities by combining gravity, magnetic and ground penetrating radar surveys: a case study from the Zaragoza area, NE Spain. Environ Geol 53: 1067-1077.

Mory AJ, Iasky RP (1996) Stratigraphy and structure of the onshore northern Perth Basin, Western Australia. Geological Survey of Western Australia, Report 46.

Murthy RV, Swamy KV, Rao JS (2001) Automatic inversion of magnetic anomalies of faults. Comput and Geosci 27: 315-325. 
Olierook HH, Timms NE, Wellmann JF, Corbel S, Wilkes PG (2015) 3D structural and stratigraphic model of the Perth Basin, Western Australia: Implications for subbasin evolution. Aust J Earth Sci 62: 447-467.

Orfanos C, Apostolopoulos G (2012) Analysis of different geophysical methods in the detection of an underground opening at a controlled test site. J Balkan Geophys Soc 15: 7-18.

Osinowo OO, Taiwo TO (2020) Analysis of high-resolution aeromagnetic (HRAM) data of Lower Benue Trough, Southeastern Nigeria, for hydrocarbon potential evaluation. NRIAG J Astron Geophys 9: 350-361.

Pisz M, Tomas A, Hegyi A (2020) Non-destructive research in the surroundings of the Roman Fort Tibiscum (today Romania). Archaeol Prospect 27: 219-238.

Powell AJ, McDonnell JG, Batt CM, Vernon RM (2012) An assessment of the magnetic response of an iron-smelting site. Archaeometry 44: 651-665.

Qureshi IR, Nalaye AM (1978) A method for the direct interpretation of magnetic anomalies caused by two-dimensional vertical faults. Geophysics 43: 179-188.

Rao AD, Babu RV (1983) Standard curves for the interpretation of magnetic anomalies over vertical faults. Geophys Res Bull 21: 71-89

Singh A, Biswas A (2016) Application of global particle swarm optimization for inversion of residual gravity anomalies over geological bodies with idealized geometries. Nat Resour Res 25: 297-314.

Singh NP, Lal T, Banerjee M (2000) Application of Hankel Transform in the interpretation of magnetic anomaly over semi-infinite vertical rod. Acta Geod Geophys 35: 143-148. 
Shah SH, Qaiser FuR, Khan NG, Mir T, Jabir M, Akram W, Muneeb-ur-Rehman M (2020) Magnetic prospecting and geochemical analysis for the mineral exploration of Mali-Dera deposits, Kohistan Island Arc-Pakistan. Environ Earth Sci 79: 406.

Tlas M, Asfahani J (2015) The simplex algorithm for best-estimate of magnetic parameters related to simple geometric-shaped structures. Math Geosci 47: 301-316.

Tlas M, Asfahani J (2011) A new best-estimate methodology for determining magnetic parameters related to field anomalies produced by buried thin dikes and horizontal cylinder-like structures. Pure Appl Geophys 168: 861-870.

Utsugi M (2019) 3-D inversion of magnetic data based on the L1-L2 norm regularization. Earth Planets Space 71: 73.

Zhao X, Zeng Z, Wu, Y, He R, Wu Q, Zhang S (2020) Interpretation of gravity and magnetic data on the hot dry rocks (HDR) delineation for the enhanced geothermal system (EGS) in Gonghe town, China. Environ Earth Sci 79: 390. 


\section{Figure captions}

Fig. 1 Sketch diagram for a two-dimensional (2D) fault-like geologic structure and its parameters.

Fig. 2 Flow-chart for the suggested approach.

Fig. 3 (a) Composite theoretical magnetic anomaly (Model 1). (b) First moving average residual magnetic anomalies for the anomaly in Figure 3a. (c) Noisy magnetic anomaly. (d) First moving average residual magnetic anomalies for anomaly in Figure 3c. (e) Geologic sketch of the 2D fault model. (f) Observed and evaluated anomalies misfits in all cases.

Fig. 4 Composite theoretical magnetic anomaly (Model 2). (b) First moving average residual magnetic anomalies for anomaly in Figure 4a. (c) Noisy magnetic anomaly. (d) First moving average residual magnetic anomalies for the anomaly in Figure 4c. (e) 2D fault sketch. (f) Observed and evaluated magnetic anomalies misfits in all cases.

Fig. 5 (a) Location and geologic map of the Perth Basin, Western Australia (after Mory and Iasky 2014). (b) Observed and calculated magnetic anomalies for the Perth Basin field example, Australia. (c) First moving average residual magnetic anomalies for the anomaly in Figure 5b. (d) Geologic model of the evaluated 2D fault. (e) Observed and evaluated magnetic anomalies misfit.

Fig. 6 (a) Location and geologic map of the Şereflikoçhisar-Aksaray fault field example, Turkey (after Bilim et al. 2015). (b) Observed and the calculated magnetic anomalies for the Aksaray fault field example, Turkey. (c) First moving average residual magnetic anomalies for the anomaly in Figure $6 b$. 

anomalies misfit. 
Figures

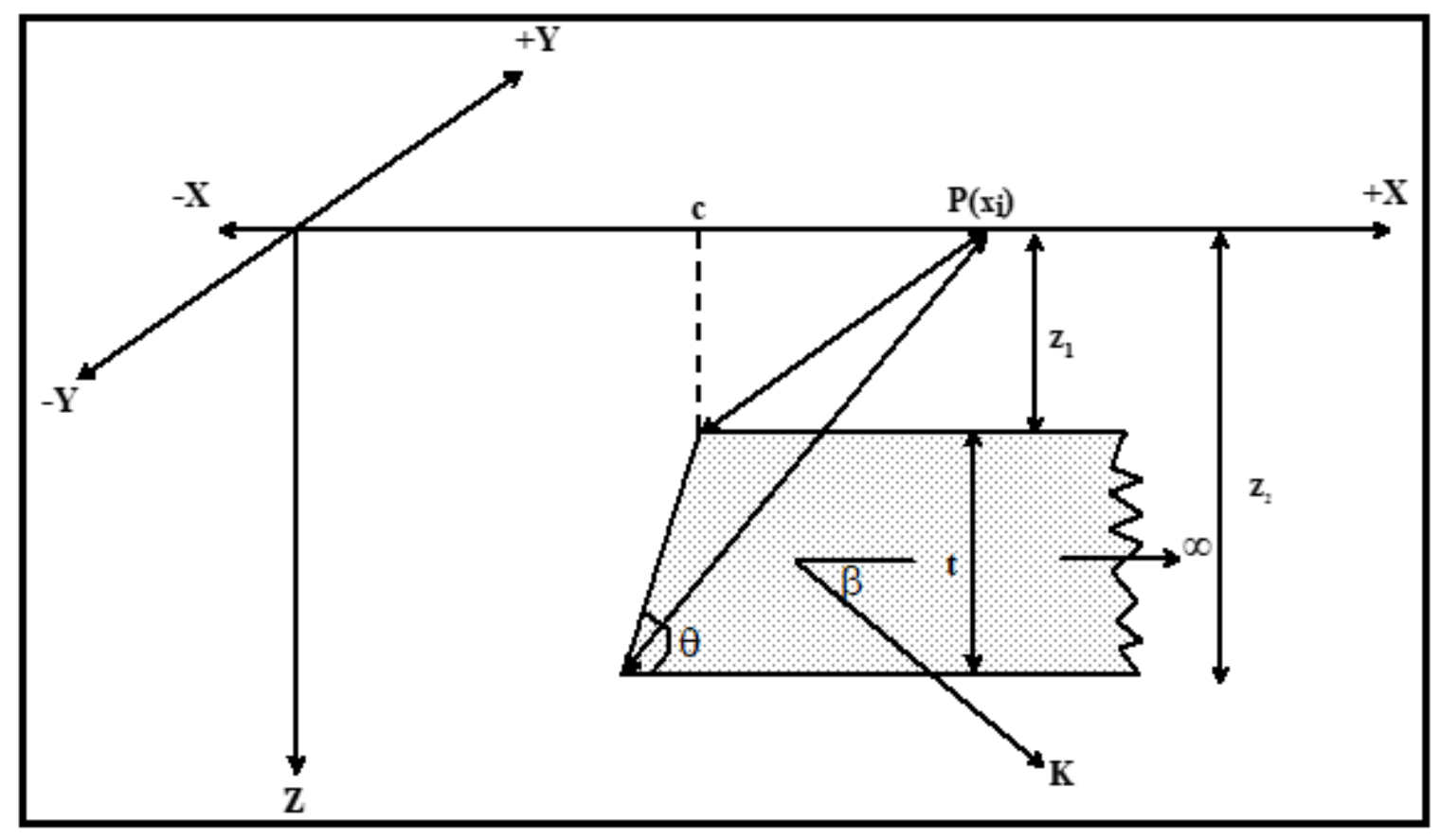

Figure 1

Sketch diagram for a two-dimensional (2D) fault-like geologic structure and its parameters. 


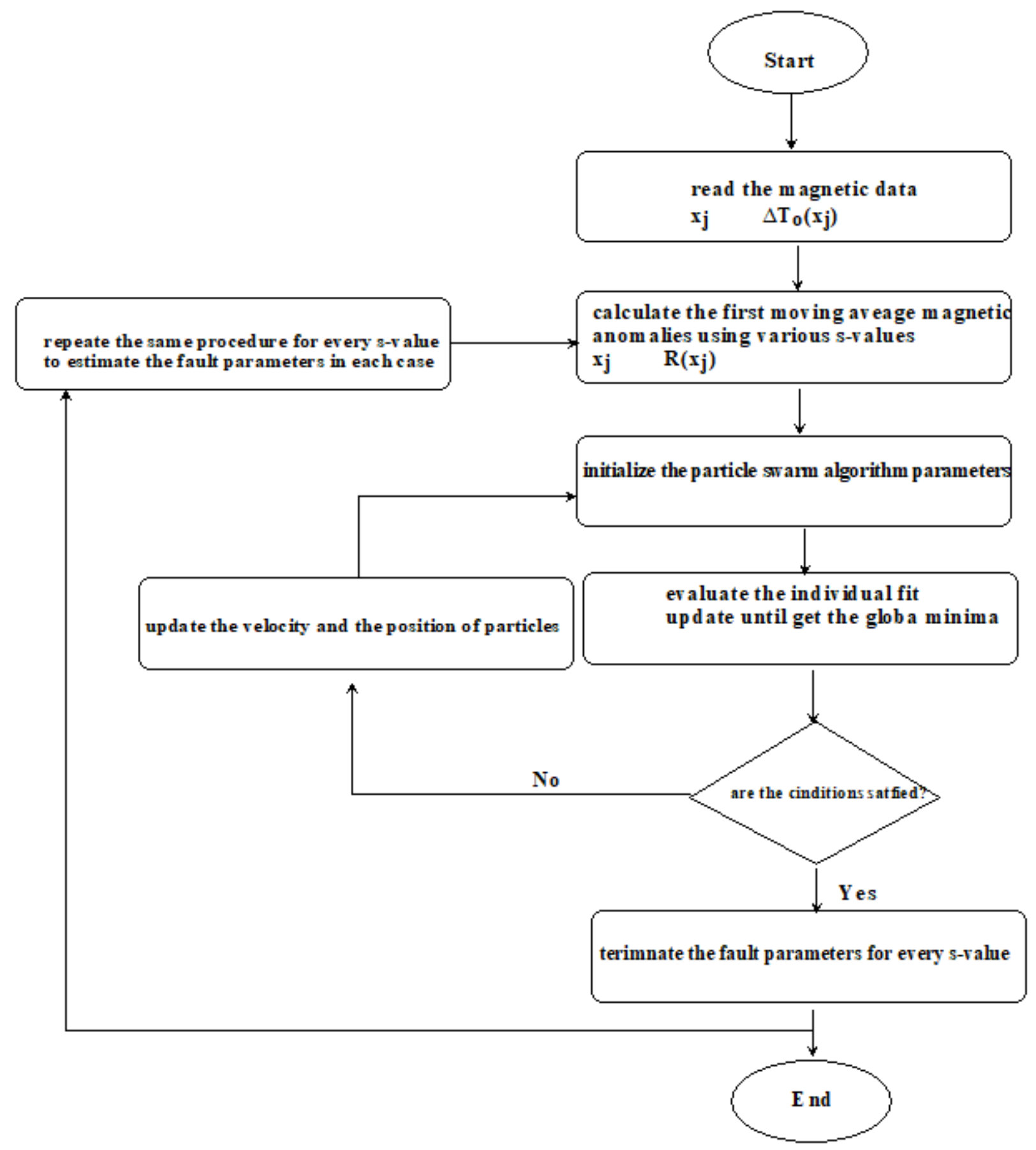

Figure 2

Flow-chart for the suggested approach. 
(a)

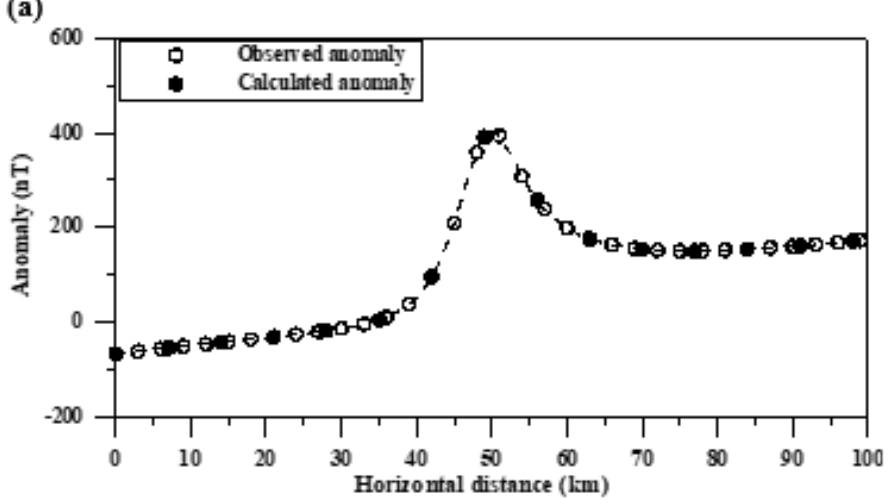

(c)

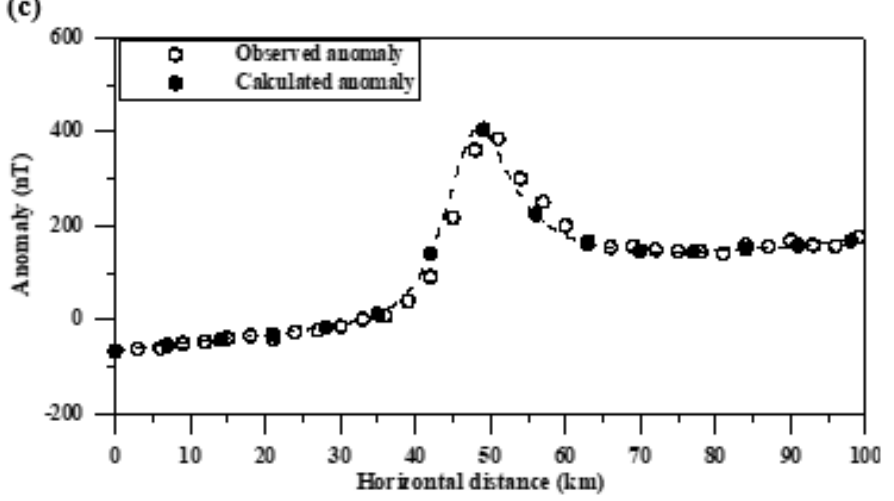

(e)

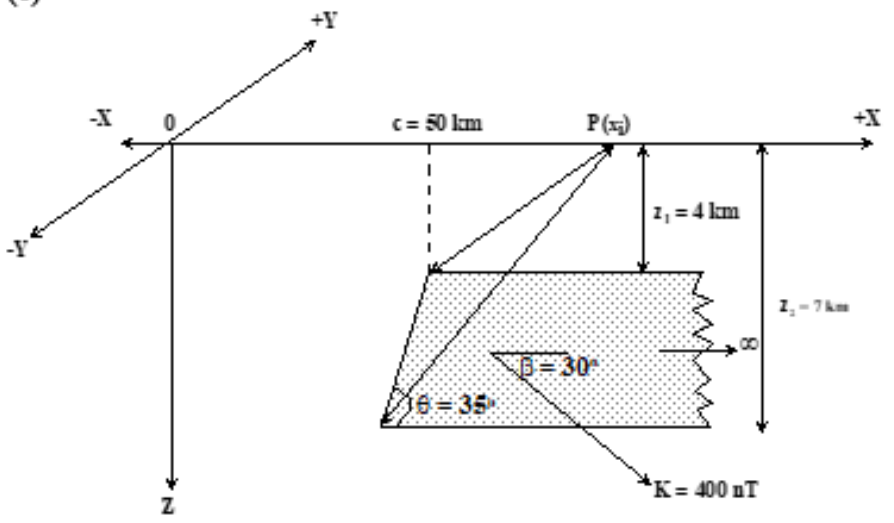

(b)

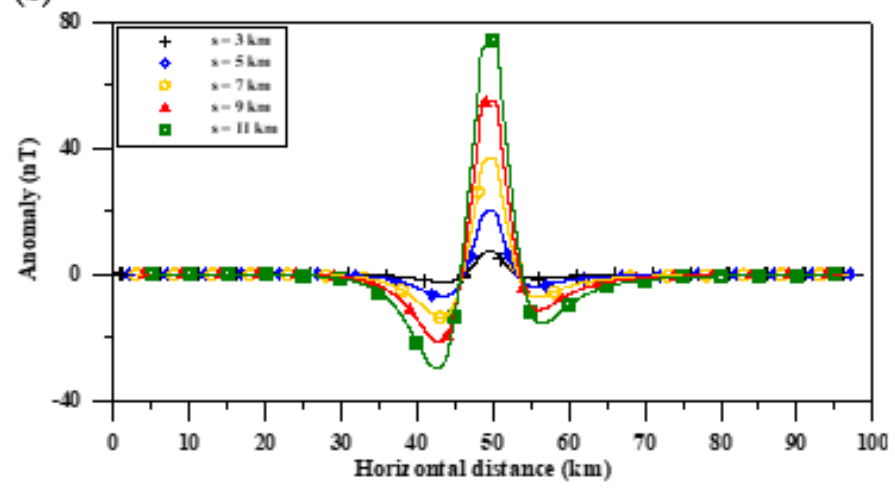

(d)

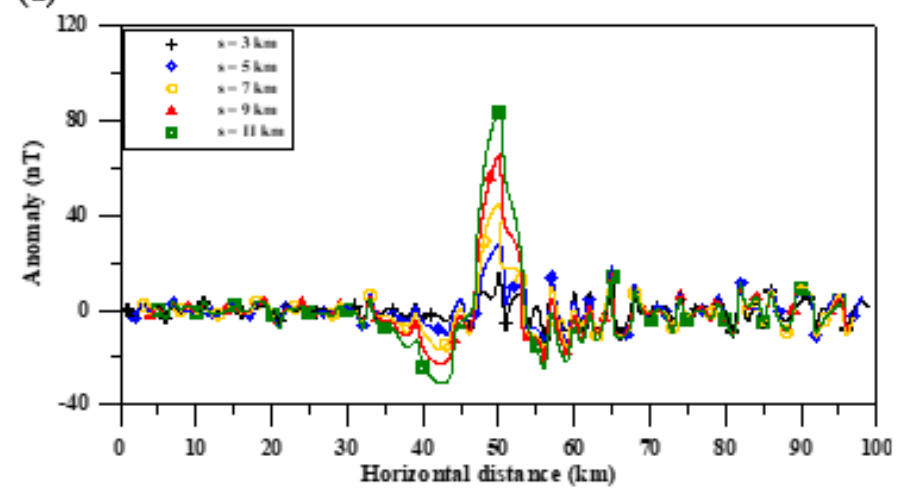

(f)

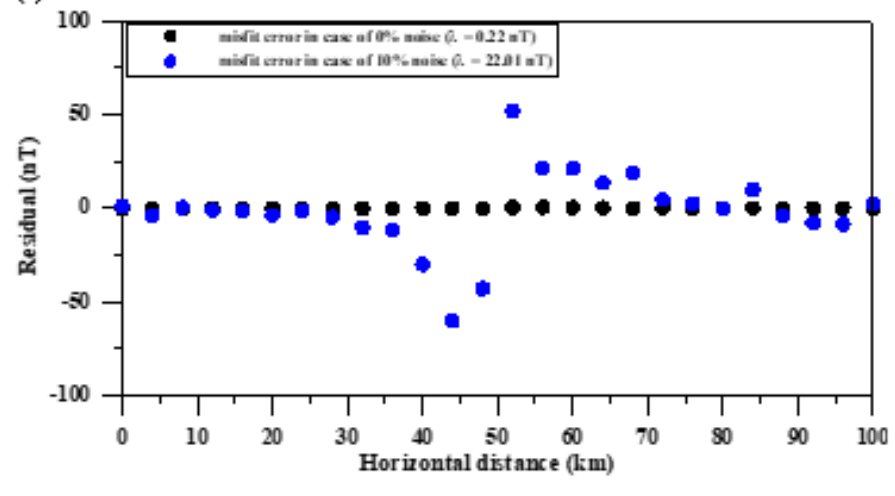

Figure 3

(a) Composite theoretical magnetic anomaly (Model 1). (b) First moving average residual magnetic anomalies for the anomaly in Figure 3a. (c) Noisy magnetic anomaly. (d) First moving average residual magnetic anomalies for anomaly in Figure 3c. (e) Geologic sketch of the 2D fault model. (f) Observed and evaluated anomalies misfits in all cases. 
(a)

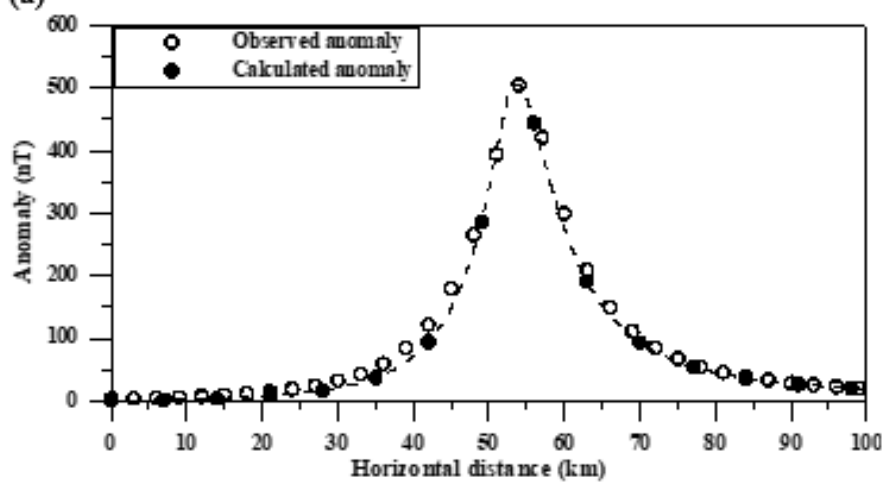

(c)

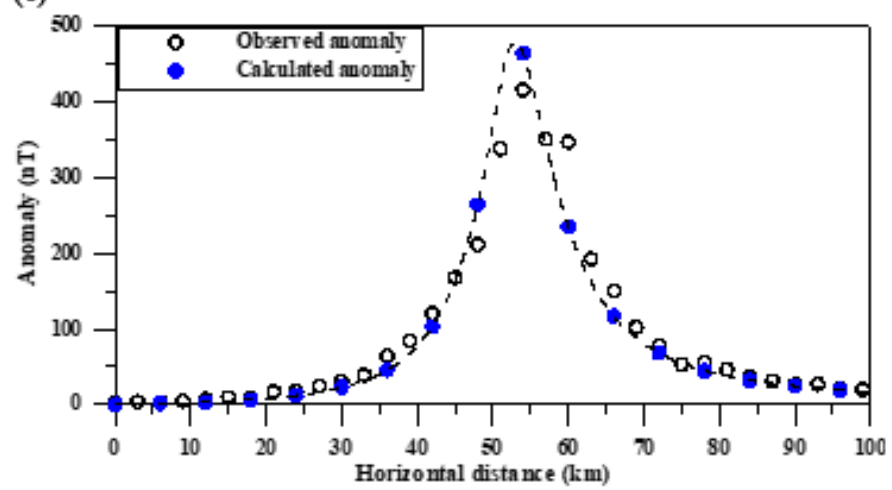

(e)

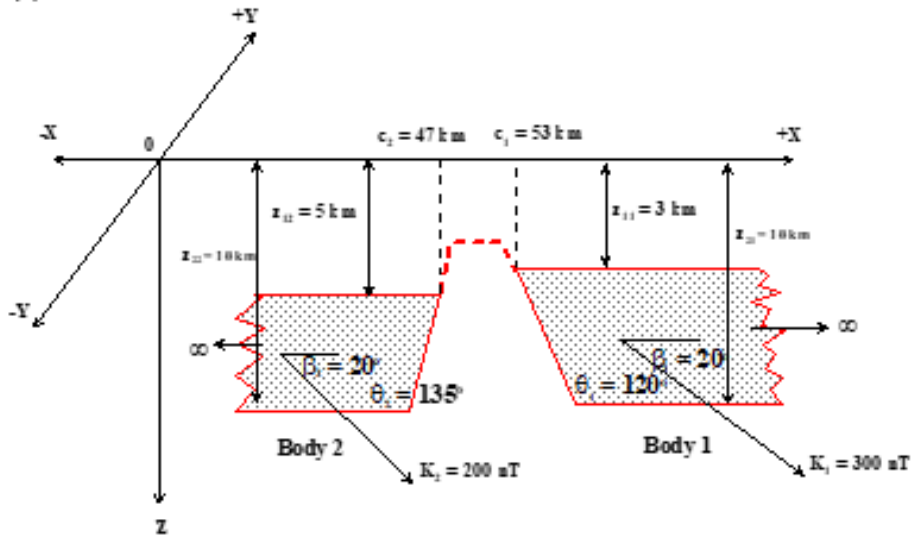

(b)

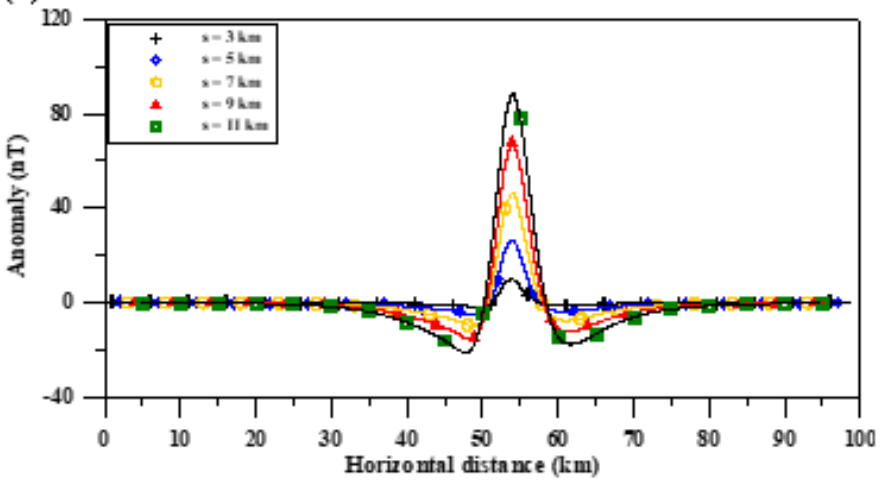

(d)

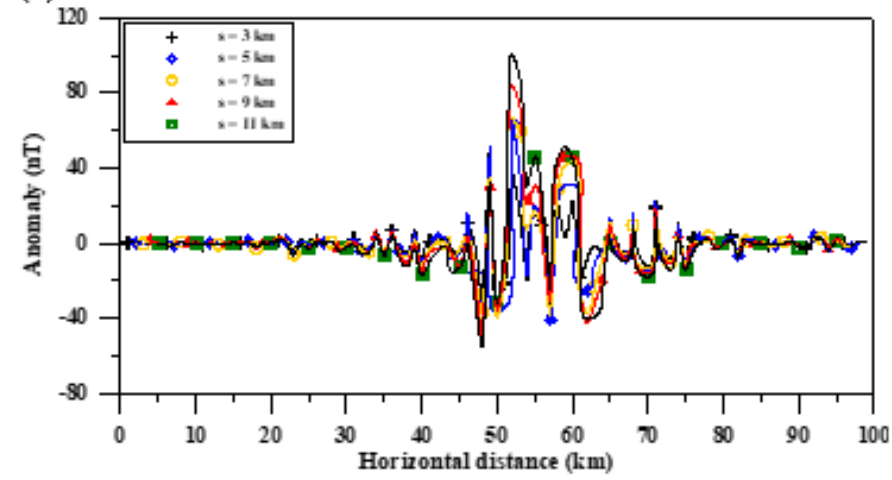

(f)

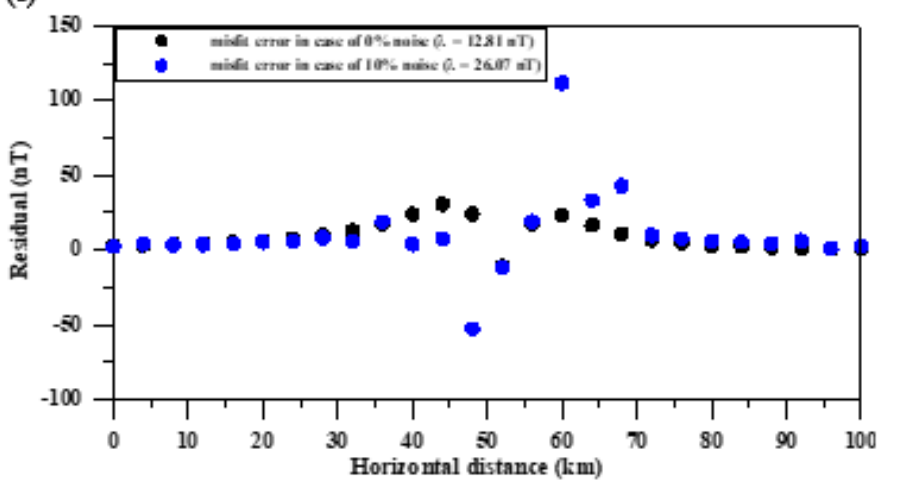

Figure 4

Composite theoretical magnetic anomaly (Model 2). (b) First moving average residual magnetic anomalies for anomaly in Figure 4a. (c) Noisy magnetic 441 anomaly. (d) First moving average residual magnetic anomalies for the anomaly in Figure 4c. (e) 2D fault sketch. (f) Observed and evaluated magnetic anomalies misfits in all cases. 

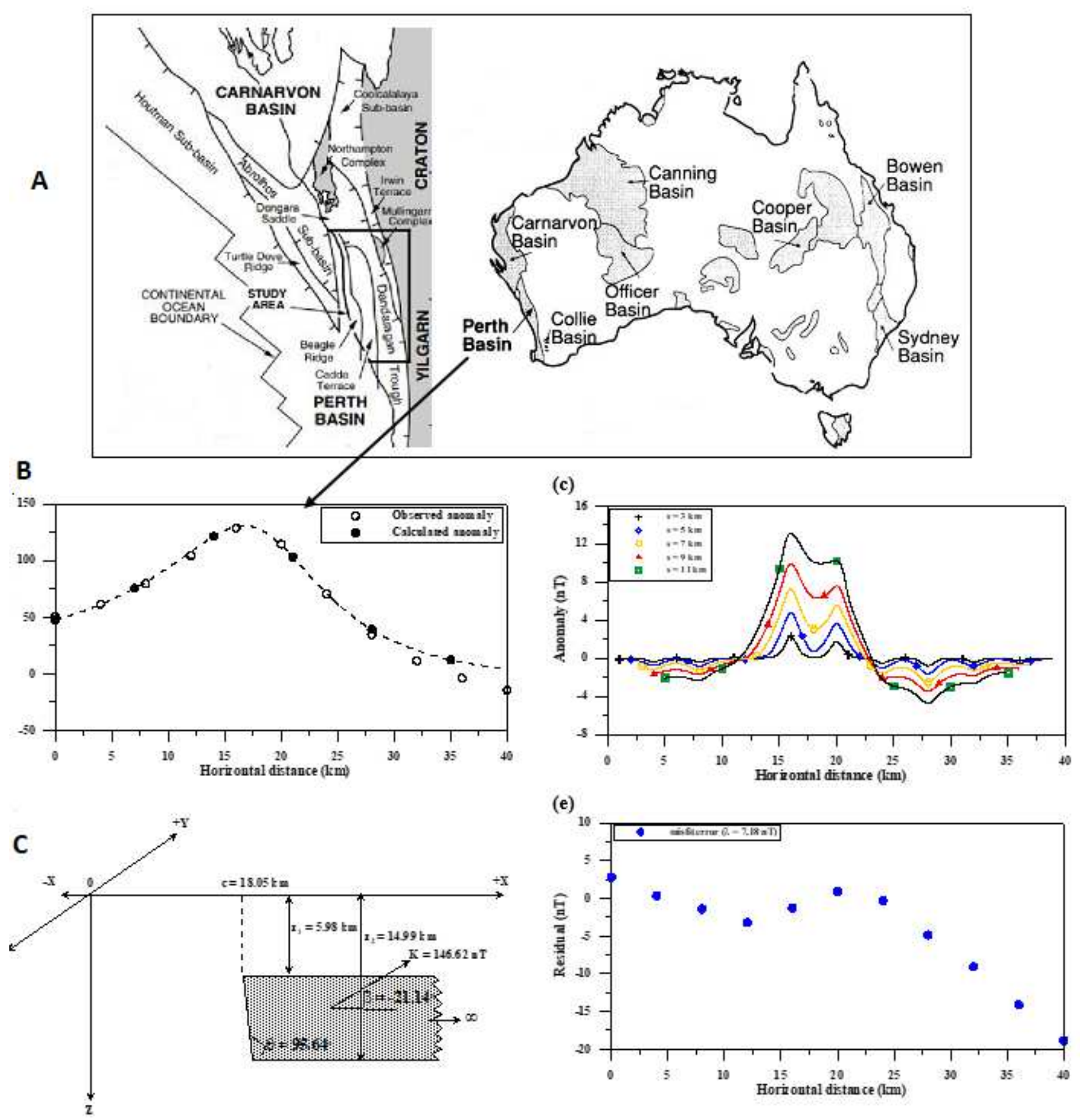

\section{Figure 5}

(a) Location and geologic map of the Perth Basin, Western Australia (after Mory and lasky 2014). (b) Observed and calculated magnetic anomalies for the Perth Basin field example, Australia. (c) First moving average residual magnetic anomalies for the anomaly in Figure 5b. (d) Geologic model of the evaluated 2D fault. (e) Observed and evaluated magnetic anomalies misfit. 
(a)
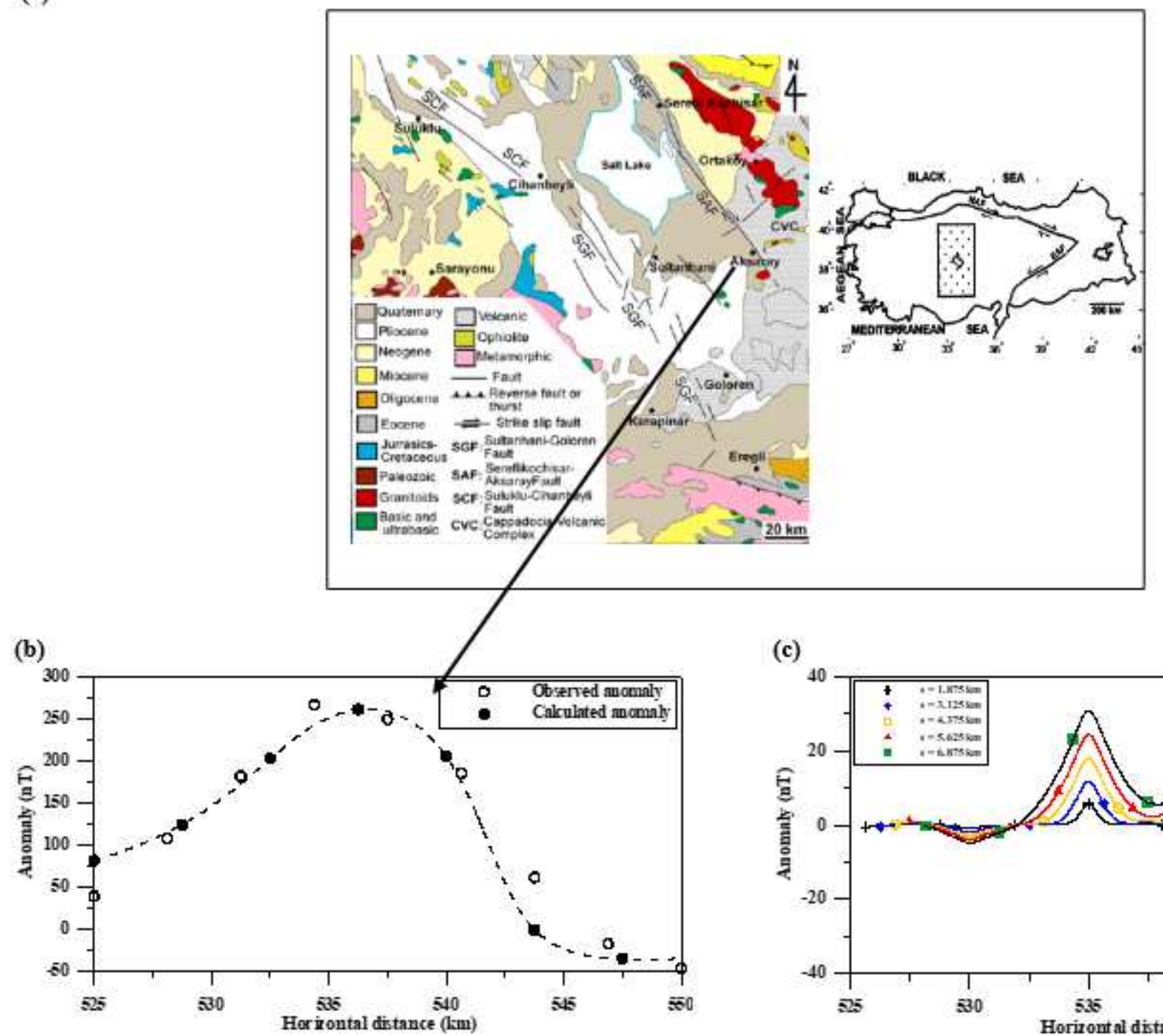

(c)
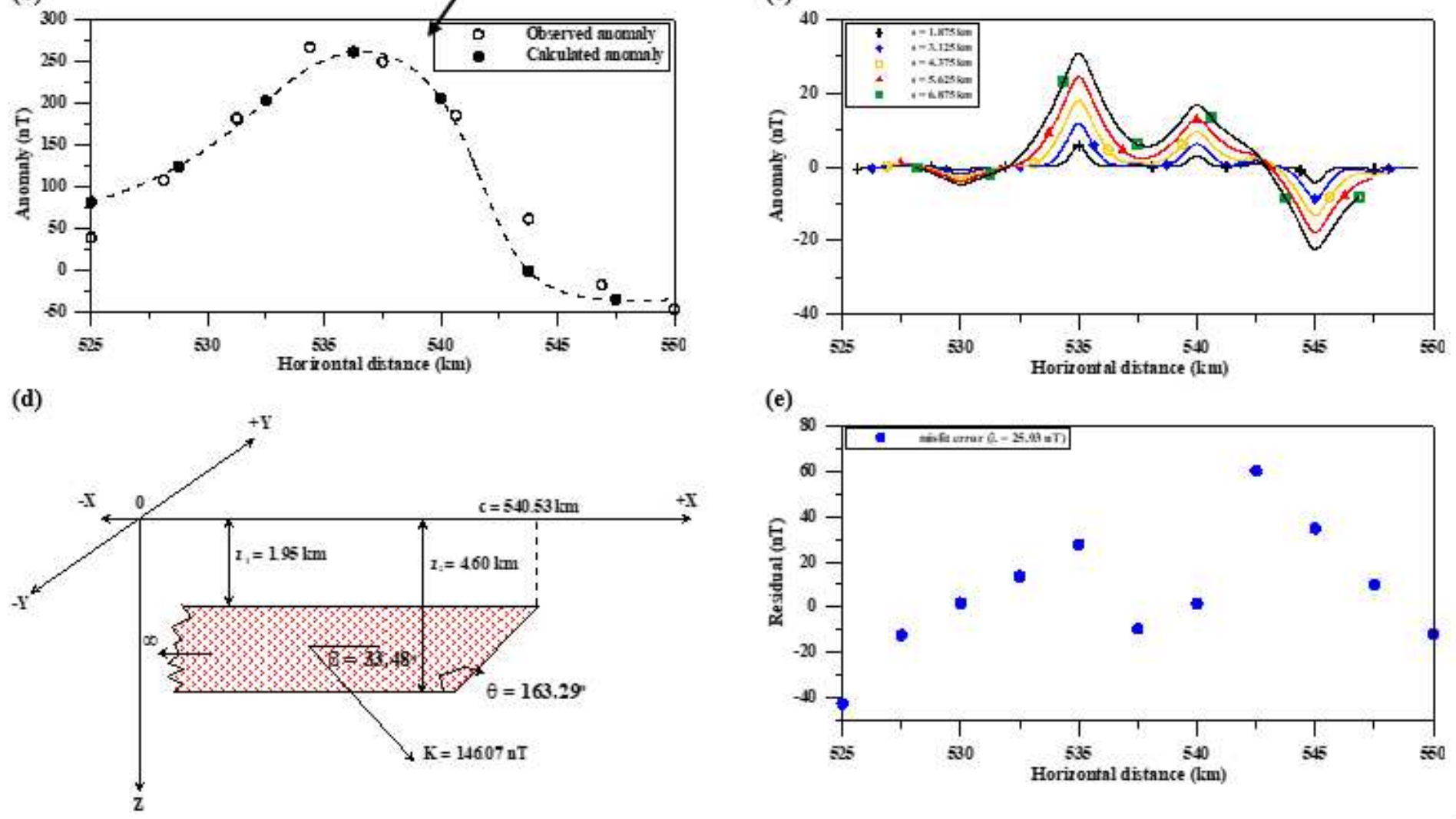

(e)

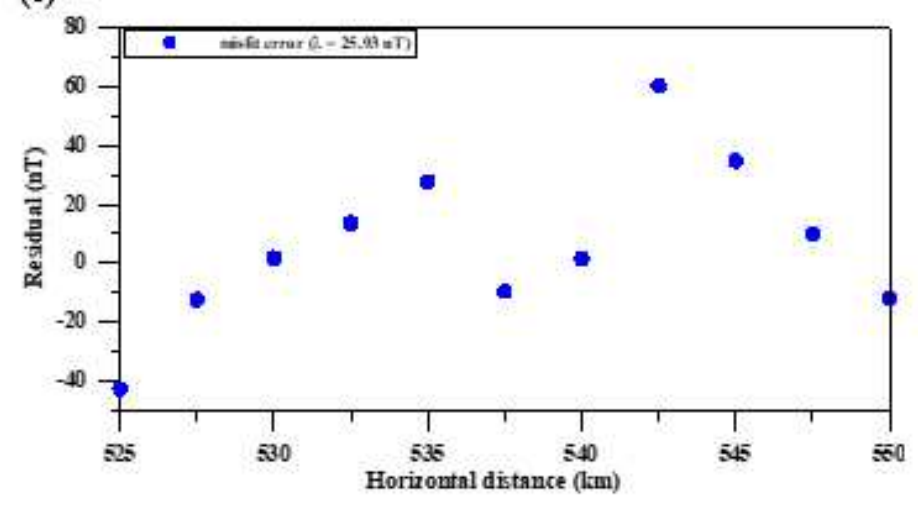

\section{Figure 6}

(a) Location and geologic map of the Şereflikoçhisar-Aksaray fault field example, Turkey (after Bilim et al. 2015). (b) Observed and the calculated magnetic anomalies for the Aksaray fault field example, Turkey. (c) First moving average residual magnetic anomalies for the anomaly in Figure $6 \mathrm{~b}$. 